\section{Feeding children in a favela in Rio de Janeiro, Brazil: how much is spent and what would be the cost of a healthy diet?}

\section{Alimentação de crianças em uma favela no Rio de Janeiro, Brasil: quanto se gasta e qual seria o custo de uma dieta saudável}

Sueli Rosa Gama 1

Letícia de Oliveira Cardoso 2 Igor Kippe Rubinsztajn 3

Audrey Fischer 4

Marilia Sá Carvalho 5

1-2 Escola Nacional de Saúde Pública. Fundação Oswaldo Cruz. Rua Leopoldo Bulhões, 1480. Rio de Janeiro, RJ, Brasil. CEP: 21041.210. E-mail: ileus@ensp.fiocruz.br

3-5 Programa de Computação Científica. Fundação Oswaldo Cruz. Rio de Janeiro, RJ, Brasil.

\begin{abstract}
Objectives: to measure food expenditure for children living in a favela in Rio de Janeiro, and compare this expenditure to the cost of a healthy diet, based on local prices.

Method: panel study, with three collection dates 2004, 2008 and 2012 - conducted in children (5 to 9 years old) in Manguinhos. Food prices were collected by way of a sample of local food stores in 2013 and deflated using indicators specific to food prices. Twenty-four hour diet recall, qualitative food frequency and the Brazilian food pyramid adequate for the age group were used to estimate the observed expenditure and the cost of a healthy diet.

Results: in 2004, 49.2\% of the families interviewed lived on less than US\$1 per person/day and $9.7 \%$ in 2012.In the same period, the percentage of students eating free school meals dropped from $73 \%$ to $49 \%$. Money spent on food was concentrated on sugary products $(32.4 \%)$ and snacks (12.5\%). The estimated monthly cost of a healthy diet (US\$142) was lower than the observed expenditure (US\$176).

Conclusions: increased purchasing power has not led to healthier food choices. The common belief that poor people choose food based on prices was rejected by the present study. Other factors certainly play an important role in food purchasing decisions.
\end{abstract}

Key words Food economics, Food Consumption, Child nutrition

\section{Resumo}

Objetivos: mensurar os gastos com a alimentação de crianças moradoras de uma favela no Rio de Janeiro e comparar com os custos de uma dieta saudável, com base em preços praticados localmente.

Métodos: estudo de painel, realizado em crianças, (5-9 anos), residentes em Manguinhos, com coletas em 2004, 2008, 2012. Os preços foram coletados em amostra de mercados locais em 2013, e deflacionados usando indicadores específicos de alimentos. Recordatório de 24 horas, frequência alimentar e pirâmide alimentar foram utilizadas na estimativa do gasto observado e custo da dieta saudável.

Resultados: em 2004, 49,2\% das famílias entrevistadas vivia com menos de um US\$1 por pessoa/dia, 9,7\% em 2012. A merenda escolar era consumida por $73 \%$ e passou a $49 \%$. O gasto com alimentos concentrou-se em produtos açucarados $(32,4 \%)$ e lanches $(12,5 \%)$. O custo mensal estimado da dieta saudável (US\$142) foi menor do que a despesa efetivamente observada (US\$176).

Conclusões: o aumento do poder de compra não levou a escolhas alimentares mais saudáveis. A crença comum de que as pessoas pobres escolhem alimentos com base nos preços foi rejeitada nesse estudo. Certamente outros fatores desempenham um papel importante nas decisões de compra de alimentos.

Palavras-chave Economia dos alimentos, Consumo de alimentos, Nutrição da criança 


\section{Introduction}

Changes to standard dietary patterns in many Western populations are associated with a pronounced increase in the prevalence of overweight and, therefore, with a rising incidence of cardiovascular diseases. 1,2 These changes are characterized by a decline in the consumption of non-processed and minimally processed foods - such as those derived directly from plants (e.g. fruit, vegetables and oils) or animals (e.g. meat, offal, and milk) and consumed soon after harvest or slaughter - and an increase in the consumption of processed, ultra-processed and ready-to-eat foods. 3,4

Dietary choices are evidently influenced by economic, social and cultural environments. Together, these factors affect access, forms of preparation and individual eating habits. Economic globalization has changed food production by modifying standards in the agricultural sector; shifting the distribution of food and commodities to large networks; and the massive spreadof fast-food chains 5 Furthermore, the industrial development of highly palatable, ultra-processed products with low nutritional value has meant that these are increasingly widely available across a vast range of economically diverse regions of the world. Publicity and marketing strategies aim to make these products desirable, sometimes with campaigns specifically targeting children. Young consumers are less able to discern the potential harm of the products, are highly impressionable and can become longer-term customers. 4,5

On the other hand, the contextualization offactors determining dietary choices has drawn renewed attention to access to, availability and price of food products, factors which may define consumption patterns for specific populations. ${ }^{5}$ Studies suggest that the food environment of an individual's area of residence is associated with the quality of his or her diet and the frequency of his or her fruit and vegetable consumption, even after controlling for individual socioeconomic factors. 6,7

Food choices at the individual level are determined by a combination of price and access, psychosocial factors and cultural factors. Perceptions of what tastes "good" or not "good" - or even the notion that lowering salt content makes something "flavorless"- are related to these variables. The role that food pricing plays in these dietary preferences and choices needs to be investigated. Consumers do not necessarily choose the cheapest products; other factors, such as flavor and availability, play a crucial role in food selection. ${ }^{8}$
In Brazil, the National Policy on Food and Nutrition (PolíticaNacional de Alimentação e Nutrição $)^{9}$ is guided by the broad principles of the Brazilian National Health System (Sistema Único de Saúde, SUS) - universality, comprehensiveness, equity, decentralization and popular participation, among others - and it adopts a comprehensive definition of food and nutritional security The recently released Food Guide for the Brazilian Population (GuiaAlimentar para a PopulaçãoBrasileira) recognizes the necessity of inter-sector action with regard to shaping the determinants of health and nutrition, and it suggests "Ten steps to an adequate and healthy diet", among them the avoidance of ultra-processed foods. The guide also reflects on how obstacles to the implementation of its proposals might be overcome. 10 Nevertheless, the cost of a healthy diet and how families perceive that cost remain largely unexplored.

Several studies have suggested a relationship between socioeconomic factors and a healthy diet.11 However, especially with regard to children's diets, research as to how local pricing affects food consumption is scarce. With this in mind, the present study aims to compare, based on local prices, the cost of feeding children aged 5 to 9 living on a favela in Rio de Janeiro, Brazil, with the estimated cost of a healthy diet as established by the Brazilian National Food and Nutrition Policy.

\section{Methods}

The study was conducted in Manguinhos, a favela located in the North Region of Rio de Janeiro, Brazil, with a population of 36,100 . It is the location of the main campus of the Oswaldo Cruz Foundation and the primary health care of the region is coordinated by the GermanoSinvalFaria School Health Center/Sergio AroucaNational School of Public Health Sergio Arouca. The prevalence of overweight/obesity in children in the same population was $24.8 \%$ in 2008.12 Thanks to largescale social and infrastructure investment, the community's Human Development Index, once the fifth lowest in Rio, is now equal to the city average (0.792). ${ }^{13}$

Data collection among the study participants - a panel study of prepubescent children, aged 5 to 9 years- began in 2004. In the next two follow-ups, in 2008 and 2012, new children within the age range were added to the study. The main aim of this cohort study was to detect childhood risk factors for developing cardiovascular diseases in adulthood. The methodology for the selection of participants is 
described elsewhere. 12 The study began with 356 children, with 126 and 152 children added in the second and third stages of data collection, respectively. Including only prepubescent children, 690 questionnaires were analyzed.Fifty-six children appearedin two rounds. To calculate estimates of food consumption, 24h-hour dietary recall questionnaire was applied to a subsample of 282 of these children, with distribution of the variables "age" and "mother's schooling" representative of those of the study population.

Food frequency questionnaires were used to evaluate consumption in all three rounds of data collection. The 2004 and 2008 rounds also included a 24-hour dietary recall in a subsample. Details of validation are presented elsewhere. 12 Questionnaires were applied to the children's caregivers, with participation of the child, by previously trained nutritionists. Furthermore, since Rio de Janeiro free schools meals are planned according to nutritional recommendations - they include grains, vegetables and fruits- data was also collected regarding participants' school meal consumption.

The following socioeconomic variables were used in analysis: level of education of head of household; per capita monthly income; and participation in a direct cash transfer program (BolsaFamília), only implemented in the area after 2008. For analytical purposes, extreme poverty was defined by the same parameters used to determine inclusion in the BolsaFamília: an income equal to or less than one dollar a day, per family member.

The following terms were used: (i) expenditure for money effectively spent buying food; (ii) cost for the money necessary to buy a healthy diet; (iii) prices - the observed prices in local commerce. In order to estimate community-specific values for monthly expenditure on a child's food and the cost of a healthy diet for children of this age group, differences in prices at large scale distributors and local establishments were taken into account. In 2013 , prices were sampled in the base community. For the 63 products listed in the food frequency questionnaire, sampling was carried out at local shops (markets, grocery stores, bakeries and butchers) in three different subareas, judged to represent the diverse characteristics of the region under study. Based on this data, the average price per unit of measurement was estimated for each food item.

The average amount of food consumption was estimated using data from the 24-hour dietary recall (only available for data from 2004 and 2008). Prices for food groups included in the questionnaire, suchas "citric fruit" or "other fruit", were calculated as a weighted average of the prices of the foods actually consumed in each category (according to the dietary recall). Monthly consumption was estimated by converting the consumption frequencies into estimates of the average number of days of consumption, as follows: eating a certain food item at least once a day was considered equivalent to 30 days a month; 2-6 times a week, 16 days a month; once a week, 4 days a month; twice a month, 2 days a month; and once a month, 1 day a month. Participants who responded that they never, or almost never, consumed a given food item were considered to have a monthly consumption of 0 . To estimate the daily cost of consumption for each food, the cost of one gram was calculated and multiplied by the average number of grams consumed in a day, according to the dietary recall. Finally, the cost per day was multiplied by the number of days of consumption per month to estimate the total cost per month.

Foods were grouped according to the Brazilian food pyramid guide (grains, fruits, vegetables, milk and its derivatives, meat, beans, sugars and fats). 14 Foods were considered processed or ultra-processed if their production involved certain treatments - such as refinement, milling, pressurizing, hydrogenation or hydrolysis - and/or certain products - oils, enzymes, margarine, butter, sugar, sweetener, salt, starch, corn syrup, milk proteins, lactose or soy. 15 The amount of these foods that children reported eating was converted into daily and monthly consumption rates according to the process described above. The total number of days of consumption per month was then multiplied by the average cost per day (according to the amount generally eaten in a day, again, as previously described).

Food prices for the first two years of data collection (2004 and 2008) were calculated using food prices from 2013 and the estimated deflation in the value of the Cesta Básica, 16 defined as a quantity of food "sufficient for the sustenance and well-being of an adult worker consuming balanced amounts of proteins, calories, iron, calcium and phosphorous" basically rice, beans, bread, meat, bananas, oil and butter. ${ }^{16}$ In order to estimate the final price for each food, the average prices, calculated by sampling community shops and markets, were adjusted to correct for changes foods might undergo through cooking processes.

The inflation rate was obtained from the consumer price index, 17 which measures changes in the cost of living for families with monthly incomes 
between 1 and 40 times the minimum monthly wage. It is the official indicator used by the Federal Government to measure economic inflation.

The nominal salary - the money that a worker receives for his work - was compared with the real salary - the goods and services that a worker can purchase with the money's purchasing power.

The Brazilian food pyramid recommendations for children was consulted, including daily serving size recommendations for all food groups, to calculate the average price of a healthy diet for the study population,. For each food group, the average cost per day was estimated using the maximum recommended number of servings (again, specific to the study population): 5 for grains, 4 for fruit, 3 for leafy greens, 2 for meat, 1 for legumes, 1 for sugars, and 1 for fatty foods. 14 According to these figures, the total daily energy intake of a balanced diet comes out as between 1683 and 2058 calories.

All descriptive statistics (proportions, deflation, mean values) were produced using the $\mathrm{R}$ statistics program. 18

\section{Results}

Of the 690 responses, $52 \%$ were recorded in the first round of interviews (2004) and 24\% in each of the subsequent rounds (2008 and 2012). These percentages include both newly added participants and a small number of reevaluations. The majority of the children's mothers $(66 \%)$ had received at least 8 years of schooling, but $18 \%$ had less than 4 years of schooling (Table 1). The percentage of all mothers who had received at least a high school education rose from $10.7 \%$, after 2004 data collection, to $15.2 \%$ by the end of the study.

Between 2008 and 2012, participation in the BolsaFamília, ranged from $40.2 \%$ to $13.6 \%$ in the study population. It was noted that the total number of families classified as living in extreme poverty dropped substantially, from almost $50 \%$ in 2004 to less than $10 \%$ in 2012 (with family income calculations including money received through the Bolsa Família). The proportion of children eating free school meals also dropped substantially, from a high of $73 \%$ to less than half that number by the final year of data collection.

Monthly spending on food for a child, updated for 2013, was approximately half of that year's minimum monthly wage, equivalent to US\$176. The distribution of the spending by food group (Figure 1) shows that $32.4 \%$ of the total spending went towards simple sugars, especially soft drinks and processed juices $(22.2 \%)$, stuffed cookies $(18.5 \%)$ and icecreams $(12,2 \%)$. While individual units of these products are inexpensive, they were consumed in large quantities.

Table 1

\begin{tabular}{|c|c|c|c|c|c|c|c|c|}
\hline \multirow{2}{*}{$\begin{array}{l}\text { Year } \\
\text { Number of children } \\
\text { Variables }\end{array}$} & \multicolumn{2}{|c|}{$\begin{array}{l}2004 \\
(356)\end{array}$} & \multicolumn{2}{|c|}{$\begin{array}{r}2008 \\
(168)\end{array}$} & \multicolumn{2}{|c|}{$\begin{array}{l}2012 \\
(166)\end{array}$} & \multicolumn{2}{|c|}{$\begin{array}{l}\text { Total } \\
(690)\end{array}$} \\
\hline & $\mathbf{n}$ & $\%$ & $\mathrm{n}$ & $\%$ & $\mathrm{n}$ & $\%$ & $\mathbf{n}$ & $\%$ \\
\hline \multicolumn{9}{|l|}{ Mother's Education* } \\
\hline Less than 4 years of study & 68 & 19.1 & 34 & 21.0 & 23 & 13.9 & 125 & 18.4 \\
\hline 4-11 years of study & 246 & 69.1 & 104 & 64.2 & 101 & 61.2 & 451 & 66.4 \\
\hline 12 or more years of study & 38 & 10.7 & 24 & 14.8 & 41 & 24.8 & 103 & 15.2 \\
\hline \multicolumn{9}{|l|}{ Income } \\
\hline Income $\leq$ US $\$ 1 /$ person/day & 175 & 49.2 & 60 & 37.3 & 16 & 9.7 & 251 & 37.0 \\
\hline \multicolumn{9}{|l|}{ School meals } \\
\hline Yes & 261 & 73.3 & 107 & 63.7 & 81 & 48.7 & 449 & 65 \\
\hline
\end{tabular}

* 4 missing data in 2004, 6 in 2008, 1 in 2012. 


\section{Figure 1}

Distribution of spending by food group.

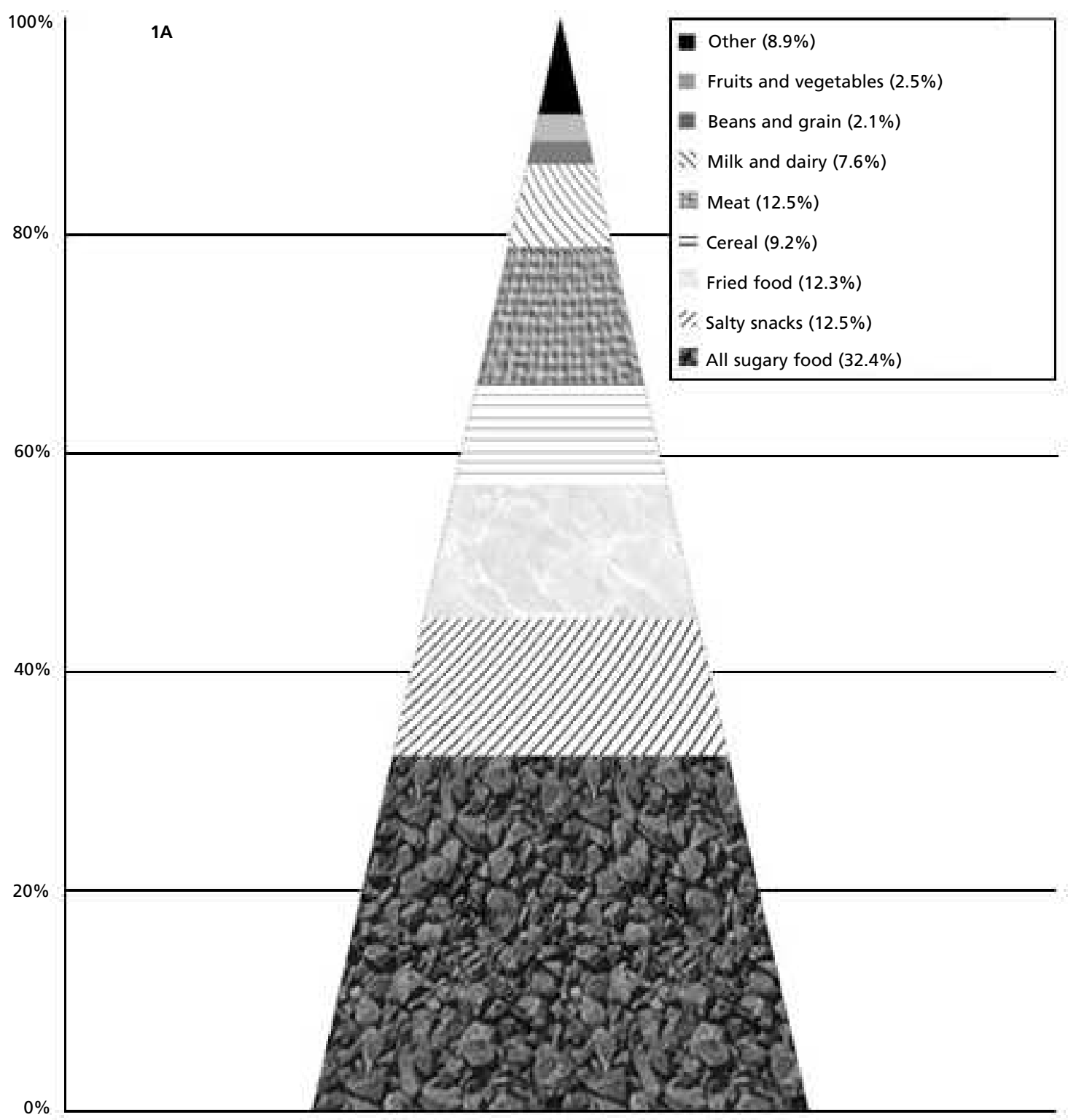

$\%$

In $1 \mathrm{~A}$ the proportion of the observed average monthly spending on feeding a child, by food group is presented. In the $1 \mathrm{~B}$ the proportion of costs of a healthy diet is presented. The food groups are not exactly matched to better explore the food consumption, with more categories. 


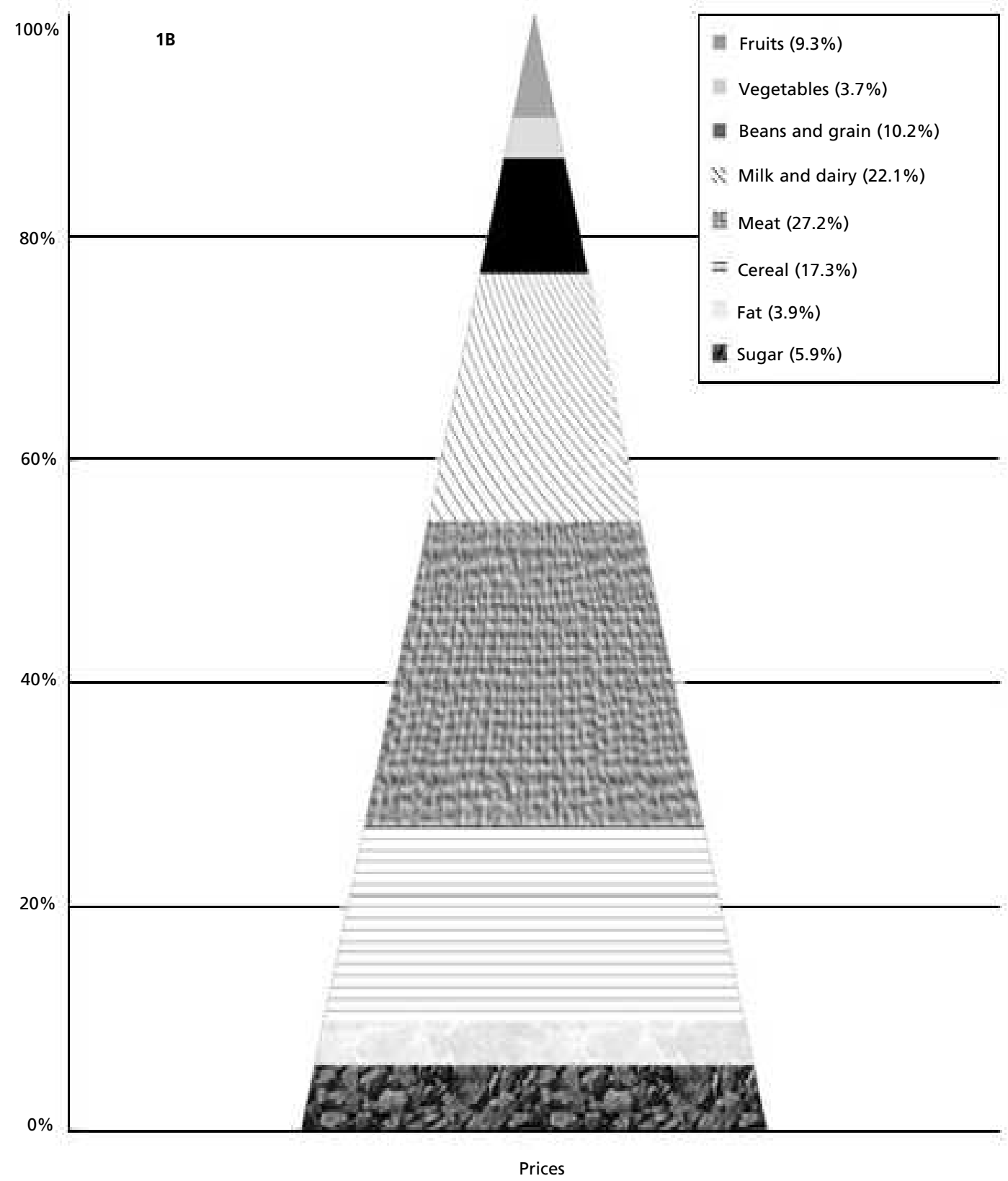

In $1 \mathrm{~A}$ the proportion of the observed average monthly spending on feeding a child, by food group is presented. In the $1 \mathrm{~B}$ the proportion of costs of a healthy diet is presented. The food groups are not exactly matched to better explore the food consumption, with more categories. 
Foods rich in fats and white flour (processed and ultra-processed foods) accounted for $24.8 \%$ of spending. The spending on meat and milk products represented $20 \%$ of the total, despite the generally higher costs of these foods. Foods considered healthy - fruit, leafy greens and vegetables - collectively accounted for only $4.6 \%$ of spending. In short, the spending pyramid did not align with the ideal food pyramid: $57.2 \%$ of all money spent went towards foods suggestive of unhealthy diets (Figure 1A). Using the same prices as those used to calculate actual monthly spending, the predicted monthly cost of a healthy diet (with the maximum number of recommended servings from each food group) amounted to US $\$ 142$, less than the actual spending. Comparing the healthy food prices pyramid (Figure 1B), the most expensive food - meat - would be a smaller proportion $(27.2 \%)$ of expenditure then the actual figure observed for sugary foods $(32.4 \%)$. Fruit and vegetables, together, in a healthy diet should account for $13 \%$ of the total amount, withless spent on fried food and snacks (24.8\%).

The trend lines in Figure 2 show increases in the nominal minimum wage, the inflation rate and the real minimum wage. The columns represent, for each round of data collection, the average monthly spending on a child's food and the estimated value of a cesta básica. The data show that, while the value of a cesta básica increased linearly - totaling a $69 \%$ increase between 2004 and 2012 - the observed average monthly spending on a child's food remained constant between 2004 and 2008 and increased by $54 \%$ between 2008 and 2012. It should be noted that monthly spending was more than $50 \%$ greater than the value of the cesta básica. The nominal minimum wage grew by $137 \%$ between 2004 and 2012 , but $50 \%$ of that growth was due to accumulated inflation. Therefore, the real minimum wage increased by $62 \%$.

Figure 2

Distribution of spending by food group.

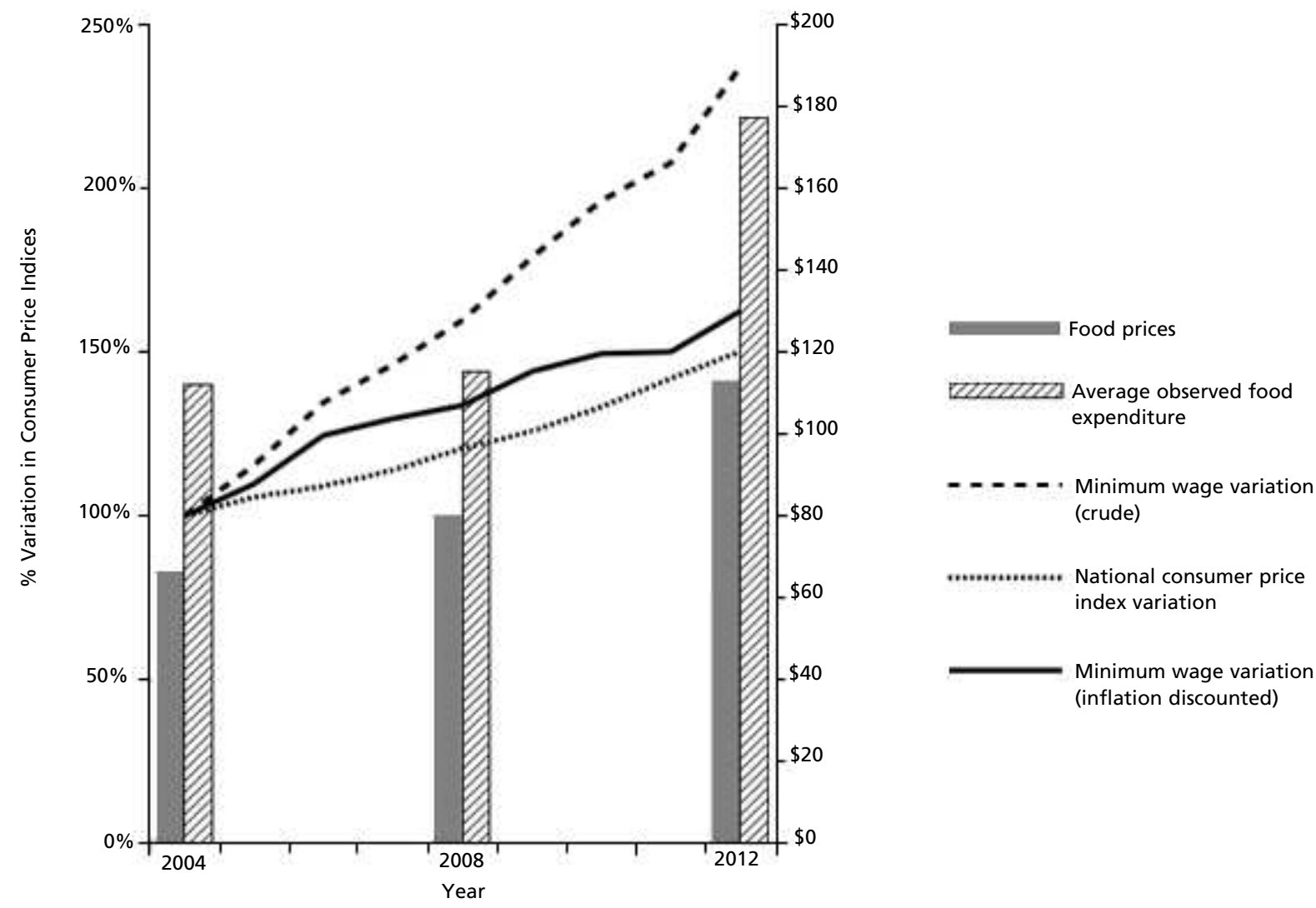

The lines show changes in the nominal minimum wage, the inflation rate and the real minimum wage. The columns represent, for each round of data collection, the average monthly spending on a child's food and the DIEESE (Inter-union Department of Statistics and Socio-economic Studies) estimated value of a cestabásica(in US\$). 


\section{Discussion}

The present study, focusing specifically on a deprived community, has identified the substantial portion of a family's budget that goes towards unhealthy foods for the family's children. To the best of our knowledge, this is the first Brazilian study to use information regarding local food availability and prices in a low-income neighborhood. A recent review ${ }^{19}$ of food choices and costs is not directly comparable to our results. Besides, the definition of healthy food, considered more expensive, is not the usual Brazilian diet.10 Another paper compared prices of healthy and unhealthy food, per serving per food type, and the differences were mostly not very great. 20 However, to the best of our knowledge, no other article used a similar approach to ours.

The decision to investigate children, rather than adults, stemmed from the idea that earlier interventions could lead to more success in combating obesity and other risk factors for cardiovascular diseases or diabetes. 1,3

This study is limited in a number of ways, especially due to the fact that prices were collected only at one specific point in time. This problem was addressed by the use of official deflators. In addition, estimates of food consumption were based on a limited subsample of participants, but this subsample had a similar profile to the rest of the children. We have no reason to suppose a specific bias in the answers to the food consumption questionnaire. Besides, if any bias did exist, it would probably be in omitting consumption of overweight children, and therefore the expenditure would be greater.

The food choices of the children of Manguinhos consisted largely of high-calorie palatable products. These products, packed with sugar, sodium and refined flour, are also nutritionally unsatisfying. ${ }^{2,15}$ A previous characterization of food consumption in 2004 indicated different patterns, one of which was composed basically of ultra-processed food. ${ }^{21}$ Many studies suggest that both taste and price act as the main determining factors in low-income families' food choices. 6,7 An individual's "taste," however, develops over a lifetime, and it is possible that the consumption of ultra-processed foods is self-perpetuating. Physiologically, these foods affect hormone levels (ghrelin and leptin systems) 22 inducing an increase in consumption and leading to a state of unchecked excess without satisfaction. This process shapes the "taste" that a child will carry over the course of his/her life. ${ }^{22}$

It is worth noting the impact that the context of the community can have on a family's food spending. Even in an urban area, with theoretically easy access to a variety of food options, local commerce affects choices. ${ }^{7}$ Deprived communities are often food deserts - places with difficult or limited access to food-based commerce - devoid of large supermarkets, and, therefore, lacking in healthy food options. ${ }^{5}$ This is the situation found in Manguinhos. Greater availability aside, high consumption of ultra-processed foods is often attributed to the lower cost, but these are offset by the vast quantities that families are consuming, as seen in Figure 1, often with little awareness of this. These eating habits have quickly and perversely taken hold in low-income communities. ${ }^{23}$ In addition, informal employment, with daily payment in very small amounts, is more common in the population living in favelas, similar to the one studied, limiting food purchases to small quantities from local suppliers. National surveys report that over $20 \%$ of the individuals employed in low-income communities work in informal jobs. 16

Food choices are also influenced by the immense selling power of ultra-processed products, based on images of "modernity", "fun" and even "happiness". These approaches, widely used by the tobacco industry, are being recycled for the sale of foods, 23 and food advertising, more often than not, leads to unhealthy eating. Studies have shown a direct effect of exposure to advertising on the eating habits and choices of children. 24

Studies conducted in developed countries indicate that diets rich in fruit and vegetables are more expensive than other options and low-income families are more likely to identify cost as a barrier to a healthy diet, electing instead to consume cheaper foods rich in processed grains, oils and sugars. 25 However, one study of American families questions the perception that unhealthy food choices are pricedependent, concluding that the cost of a healthy diet varies greatly. 25

Traditional Brazilian food has never emphasized fruit and vegetable consumption, but it has been based around healthy staple foodstuffs, particularly rice and beans. 26 This healthy dietary base is now being replaced by ultra-processed products. In addition, time spent on food preparation is dropping, as is the number of family meals. The current Brazilian Food Guide recognizes these trends, highlighting the importance of traditional family dietary practice. 10

In the present study, the observed monthly spending on a child's food proved similar to the cost of a healthy diet, which can be attributed to several 
factors. For one, the way unhealthy, processed products are packaged - in small volumes at low prices leads buyers to believe that they are getting a good deal. 25 Nonetheless, in the large quantities being purchased, these individually cheap items become expensive collectively. In addition, an American study has suggested that when prices are based on weight or serving size, grains, vegetables, fruit and milk are cheaper than most proteins or ultraprocessed foods. 27

The period under study was marked by changes in social policies, with increases in the real minimum wage leading to greater purchasing power for lowincome groups. ${ }^{28}$ It is possible that this upward social mobility has also led to increased access to industrialized products. Public school cafeterias follow government standards for healthy eating, but the proportion of students eating at school has dropped. This could be the result of both a social devaluing of school meals, linked to poverty in popular perception, and a new, socially valued way of eating, with its own globalized culinary culture, fostered by the processed food industry.

While the Food Guide 10 proposes useful strategies, ranging from limiting consumption of ultraprocessed foods to encouraging a return to traditional, family food systems, it is important to consider the barriers to implementing these proposals in lower-income communities. Increasingly, women work away from home 8 and children share housekeeping responsibilities. While the food guide suggests that men, women and, indeed, all members of the family should participate in food preparation, these tasks are still socially devalued, leading to a continuing resistance to sharing domestic responsibilities. ${ }^{29}$

Social measures, such as home economics lessons and nutritional education programs, could prove ineffective in changing eating habits if they are not accompanied by economic measures aimed at making a healthy diet more accessible to modern, low-income families with working mothers. Serious studies are needed regarding agricultural subsidies, reassessing import taxes and reformulating food assistance programs, with the specific goal of bettering access to nutritious, unprocessed foods in low-income populations. The food and nutrition security system includes a National Policy on Food Supply, 30 which could contribute significantly to these discussions.

Finally, well-implemented regulatory measures could substantially curb unhealthy eating patterns, thereby also addressing concerns regarding the incidence of diseases related to cardiovascular health. These measures could include restrictions on abusive marketing and publicity campaigns, often aimed specifically at children, for foods rich in fat, sugar and salt; limits to the types of food that can be sold in or around schools; and requirements regarding the information that must be included on food labels, including sugar and salt content.

The positive impact of social policies in Brazil especially the cash transfer program and increase in the minimum wage - can be seen in the study population through a drop in the percentage of people living below the poverty line. A large percentage of the observed spending on food for children went towards unhealthy, ultra-processed foods. The estimated monthly cost of a healthy diet was slightly lower than the observed monthly spending, leading to the conclusion that food choices are determined by a diverse range of factors, many unrelated to pricing.

Implementing a policy that would have a real impact on nutrition depends on recognizing the complex realities of the present day food culture, including the facts that: (i) "taste" is conditioned by the palatability of industrialized foods; (ii) unhealthy habits, such as drinking soft drinks with meals and constantly snacking are hard to change; (iii) mothers now usually spend the day at work, away from home, and have very little time to cook; (iv) creating and maintaining a home supply of healthy foods is a difficult task. These factors interact with one another creating a complex reality and cannot be treated separately. A return to traditional food systems is extremely difficult in the real day-to-day lives of modern families. Therefore, to encourage healthy eating in a true urban context, new strategies must be considered, ranging from nutritional education to subsidies on healthy foods, from bans on industry marketing strategies targeting children to taxes on ultra-processed foods.

\section{References}

1. Frederick CB, Snellman K, Putnam RD. Increasing socioeconomic disparities in adolescent obesity. ProcNatlAcadSci USA. 2014; 111 (4): 1338-42.
2. Monteiro CA, Moubarac J-C, Cannon G, Ng SW, Popkin B Ultra-processed products are becoming dominant in the global food system. Obes Rev. 2013; 14: 21-8. 
3. Popkin BM, Adair LS, Ng SW. The Global Nutrition Transition: The Pandemic of Obesity in Developing Countries. Nutr Rev. 2012; 70 (1): 3-21.

4. King DA, Thomas SM. Big lessons for a healthy future. Nature. 2007; 449 (7164): 791-2.

5. White M. Food access and obesity. Obes Rev. 2007; 8: 99 107.

6. Caspi CE, Sorensen G, Subramanian SV, Kawachi I. The local food environment and diet: A systematic review. Health Place. 2012; 18 (5): 1172-87.

7. Moore LV, Diez Roux AV. Associations of neighborhood characteristics with the location and type of food stores. Am J Public Health. 2006; 96 (2): 325-31.

8. Canesqui AM. Maria, Garcia RW. Antropologia e nutrição: um diálogo possível. Rio de Janeiro: Editora Fiocruz; 2005.

9. Ministério da Saúde. Política Nacional de Alimentação e Nutrição (PNAN). Ministério da Saúde; 2012.

10. Brasil. Ministerio da Saúde. Guia Alimentar para a População Brasileira-2014. Disponível em:http://189.28.128.100/dab/docs/portaldab/publicacoes/g uia_alimentar_populacao_brasileira.pdf

11. Powell LM, Bao Y. Food prices, access to food outlets and child weight. Econ Hum Biol. 2009; 7 (1): 64-72.

12. Gama SR, Carvalho MS, Cardoso L de O, Chaves CRM de M, Engstrom EM. Cohort study for monitoring cardiovascular risk factors in children using a primary health care service: methods and initial results. Cad Saúde Pública. 2011; 27 (3): 510-20.

13. Ipea/Pnud, Fundação João Pinheiro. Atlas do Desenvolvimento Humano no Brasil . Consulta| Atlas do Desenvolvimento Humano no Brasil. [acesso em $7 \mathrm{dez}$ 2014]. Disponível em: http://www.atlasbrasil.org.br/ 2013/pt/consulta

14. Philippi ST, Latterza AR, Cruz ATR, Ribeiro LC. Pirâmide Alimentar adaptada: Guia para Escolha dos Alimentos. Rev Nutr. 1999; 12 (1): 65-80.

15. Monteiro CA, Levy RB, Claro RM, Castro IRR de, Cannon G. A new classification of foods based on the extent and purpose of their processing. Cad Saúde Pública. 2010;26 (11): 2039-49.

16. DIEESE (Departamento Intersindical de Estatística e Estudos Socioeconômicos). Cesta Básica Nacional - Salário Mínimo Nominal e Necessário. [acesso 17 ago 2014]. Disponível em: http://www.dieese.org.br/analisecestabasica/salarioMinimo.html

17. Índice Nacional de Preços ao Consumidor Amplo - IPCA Portal Brasileiro de Dados Abertos. [acesso em 29 set 2014]. Disponível em: http://dados.gov.br/dataset/indicenacional-de-precos-ao-consumidor-amplo-ipca
18. The R Project for Statistical Computing. [acesso em 5 dez 2014]. Disponível em: http://www.r-project.org/

19. Drewnowski A, Darmon N. Food Choices and Diet Costs: an Economic Analysis. J Nutr. 2005; 135 (4): 900-4

20. Rao M, Afshin A, Singh G, Mozaffarian D. Do healthier foods and diet patterns cost more than less healthy options? A systematic review and meta-analysis 2013.BMJ Open.2013; 3 (12): e004277.

21. Gama SR, Carvalho MS, Chaves CRM de M. [Childhoodprevalenceof cardiovascular riskfactors]. Cad Saúde Pública. 2007; 23 (9): 2239-45.

22. Drewnowski A. Energy density, palatability, and satiety: implications for weight control. Nutr Rev. 1998; 56 (12): $347-53$

23. Nestle M. Food Politics: How the Food Industry Influences Nutrition and Health. 1 ed. Berkeley Calif:University of California Press; 2003.

24. Boyce T. The media and obesity.Obes Rev. 2007; 8: 201-5.

25. Carlson A, Frazão E. Food costs, diet quality and energy balance in the United States. PhysiolBehav. 2014; 134: 2031.

26. Sichieri R, Castro JFG, Moura AS. Factors associated with dietary patterns in the urban Brazilian population. Cad SaúdePública. 2003; 19: S47-53.

27. Carlson A, Frazão E. Are Healthy Foods Really More Expensive? It Depends You Meas Price. EIB-96,U.S. Departament of Agriculture, Economic Research Service, 2012

28. Nery M. The New middle class in Brazil: the bright side of the poor. [acesso em $27 \mathrm{fev}$ 2015]; disponivelem: http://www.cps.fgv.br/ibrecps/ncm2010_eng/NMC_Resear ch_FGV_CPS_Neri_FORMAT_ENG_FIM_apres_SITE.pd

29. Porto M. A mulher brasileira nos espaços público e privado. Fundação Perseu Abramo; [acesso em 16 jan 2015]. Disponível em: http://library.fes.de/pdffiles/bueros/brasilien/05629-introd.pdf

30. Consea. Construção do Sistema e da Política Nacional de Segurança Alimentar e Nutricional: a experiência brasileira. [acesso em 13 mar 2015]. Disponível em https://www.fao.org.br/download/Seguranca_Alimentar_Po rtugues.pdf
Recebido em 13 de agosto de 2015

Versão final apresentada em 18 de setembro de 2015

Aprovado em 09 de outubro de 2015 